\title{
On the Hydroid of Laodicea undulata (Forbes and Goodsir)
}

\author{
By
}

F. S. Russell,

Naturalist at the Plymouth Laboratory.

With 7 Figures in the Text.

IN 1866 Hincks described the hydroid Cuspidella humilis: later, in his History of the British Hydroid Zoophytes (1868, p. 210), he added two further species to the genus, $C$. grandis and C. costata. At that time the reproduction of Cuspidella was not known.

Metschnikoff (1886, p. 83 and Taf. V, Fig. 1) described the development of the eggs of Laodicea cruciata and reared them to the hydroid stage. These had sessile hydranths and elongated polyps with ten slender tentacles, long and short alternating. Metschnikoff remarked on their similarity to Cuspidella.

In 1906 Browne (1907, p. 464) received a letter, with drawings, from Miss M. J. Delap of Valencia Island, Ireland, saying that she had kept a colony of Cuspidella costata from which medusæ were liberated. Examination of these medusæ led Browne, after comparison with young stages taken in the tow-net, to the conclusion that they were Laodicea undulata. The hydrothecæ of Miss Delap's Cuspidella had the transverse rings as shown in Hincks' drawing of C. costata (1868, Pl. 40, Figs. 5 and 5a), but the hydroid reared by Metschnikoff lacked these rings. Hincks (1868, p. 211) regarded these as growth rings and their method of formation has been described by Ritchie (1910, p. 814 ; Pl. LXXVII, Fig. 8).

Browne (1907, p. 464) presumed that Metschnikoff's L. cruciata was L. mediterranea (Gegenbaur), and Kramp (1919, pp. 21-25) in a critical discussion of the species of Laodicea has concluded that $L$. mediterranea is synonymous with L. undulata (Forbes and Goodsir).

In September, 1935, a number of hydroid colonies were successfully reared in the laboratory at Plymouth from Laodicea undulata. These confirm the previous observations that the hydroid of this species is a Cuspidella.

\section{Description of Hydroids Reared in Laboratory.}

The majority of the hydroids were single individuals in which one hydrotheca had developed at the end of the stolon (Fig. 1). In most isolated individuals the hydrotheca was attached to the substratum for 
about half its length, when it then curved upwards (Fig. 2) (cf. Ritchie, 1910, p. 814). Where a large number of planulæ had settled together and a close clump of hydroids had been formed, the central hydrothecæ were growing upwards (Fig. 3). In some colonies kept alive for a considerable period more than one hydrotheca was

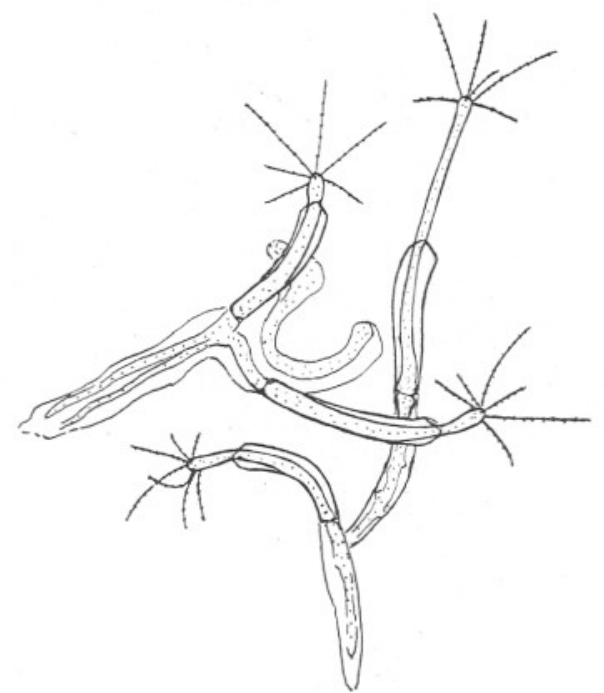

FrG. 1.-Early stages of Cuspidella reared from Laodicea at Plymouth, September, 1935.

developed and these came off at right angles from the stolon with no indication of $\mathrm{a}^{\prime}$ stalk (Fig. 4, A-B). The hydrothecæ varied considerably in length (Fig. 4, A-E) and individuals could be found varying between the short type, $C$. humilis, and the more elongated $C$. grandis (Hincks, 1868, Pl. 39, Fig. 4A, and Pl. 40, Fig. 4). In one vessel in which

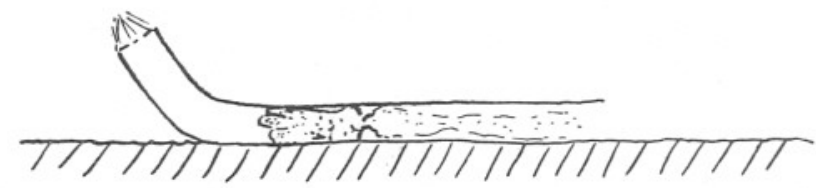

FIG. 2.-Cuspidella reared from Laodicea at Plymouth, September, 1935, showing how hydrotheca may be attached to the substratum for half its length before curving upwards.

the water was kept agitated the hydroids lived for several weeks, and a number of the hydrothecæ were then found to have developed growth rings (Fig. 4, F), and were of normal type, while in still water they had grown into filamentous formless stolons.

The transition from the stolon to the hydrotheca was marked by a hardly discernible diaphragm (Fig. 5, A). This diaphragm is not mentioned 
by Hincks, but Hartlaub (1897, p. 503, and Taf. XX, Figs. 17 and 18) remarks that the hydranth is clearly marked off from its stalk in C.grandis. A diaphragm is described by Spassky $(1929$, p. 37$)$ in his new species $C$. mollis. In the Plymouth specimens a ring of a few irregularly spaced spines is also visible above the diaphragm (Fig. 5, A) as described by Spassky in $C$. mollis. In well-preserved individuals these spines can

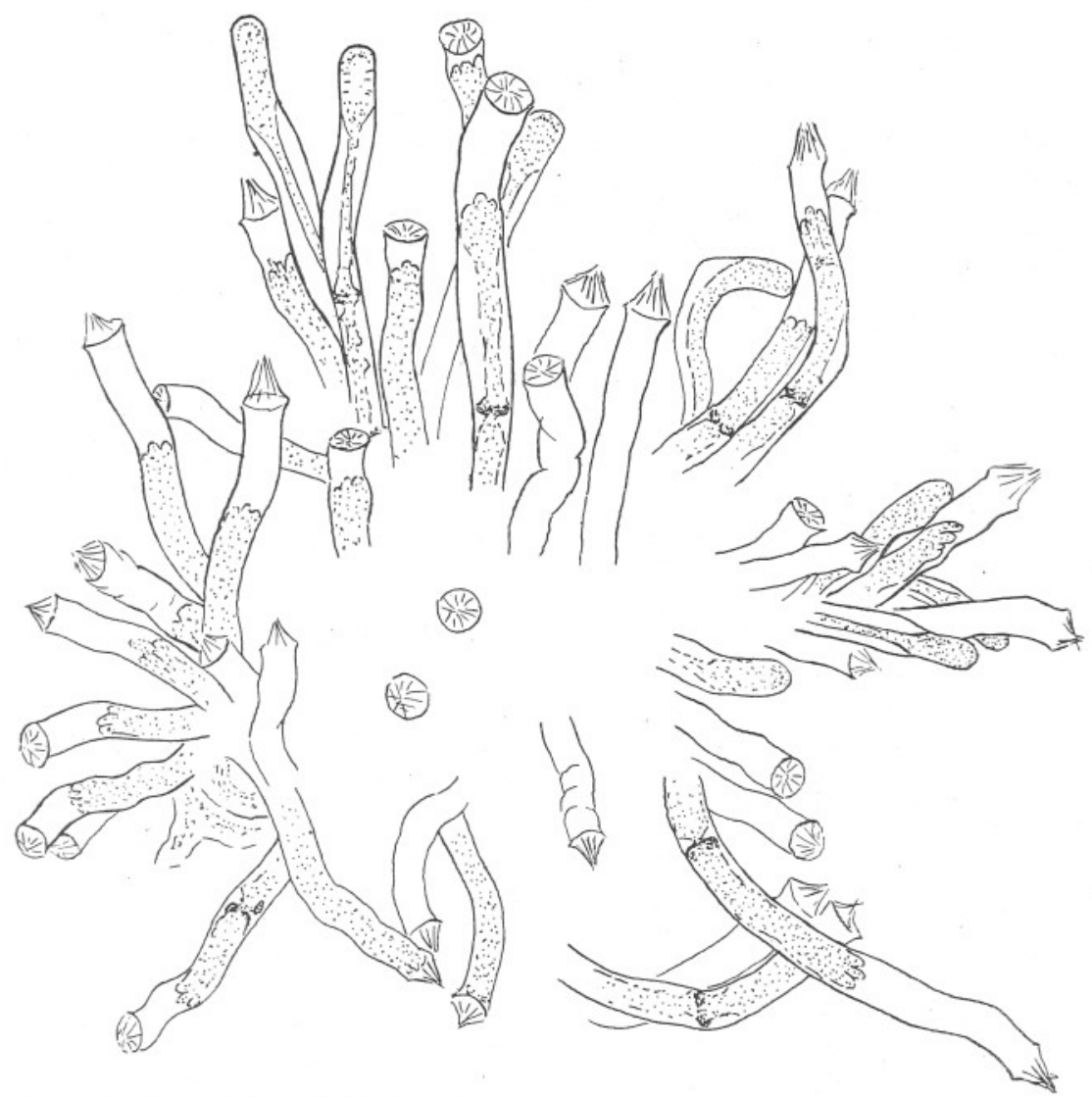

FIG. 3.-Clump of Cuspidella hydroids reared from Laodicea at Plymouth, September, 1935: many individuals in the centre have been omitted from the drawing.

be clearly seen acting apparently as points of attachments for the basal tissue of the hydranth (Fig. 5, в). The hydrotheca is crowned by the typical Cuspidella operculum consisting of a number of triangular folded facets in direct continuation with the perisarc of the hydrotheca (see Kramp, 1911, p. 379, and 1932, p. 23).

The length of the hydrotheca measured from the diaphragm to the base of the operculum varied from $0.28 \mathrm{~mm}$. to $0.95 \mathrm{~mm}$., and the width was 
$0 \cdot 09-0 \cdot 11 \mathrm{~mm}$. The length of the opercular teeth approximates to the width of the hydrotheca.

The polyp is very extensile and can extend to twice the length of the

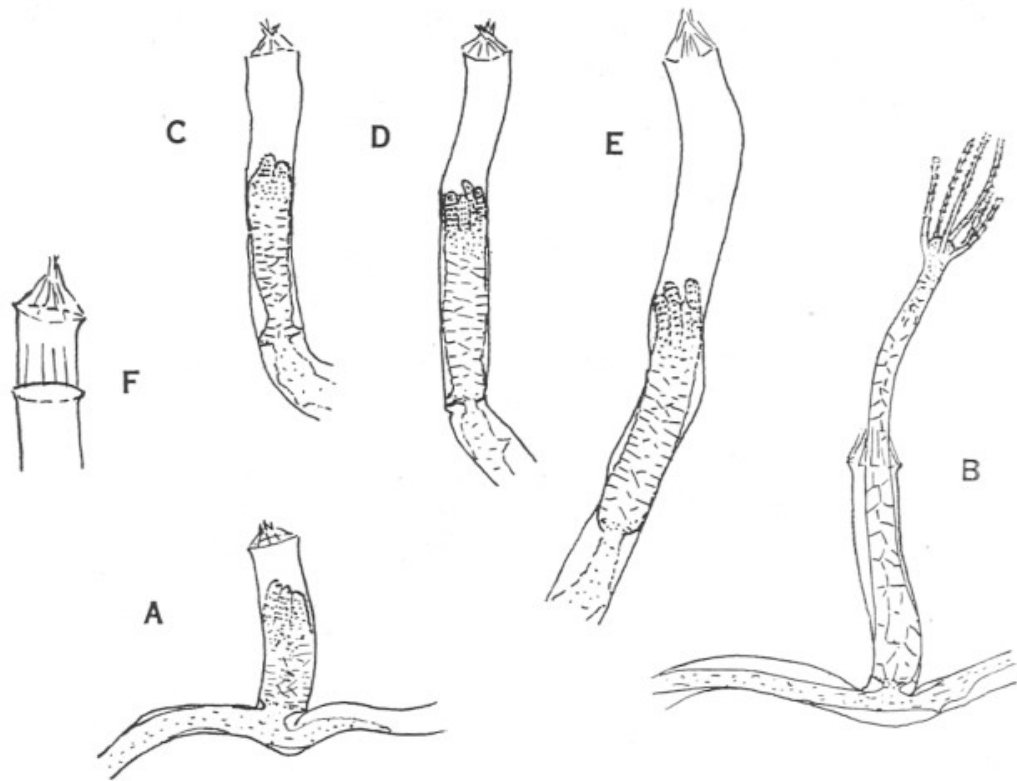

FIG. 4.-Cuspidella reared from Laodicea at Plymouth, September, 1935. A, hydrotheca growing off at right angles to stolon, C. humilis type, hydrotheca $0.28 \mathrm{~mm}$. long: $\mathrm{B}$, preserved specimen with polyp extended, hydrotheca $0.42 \mathrm{~mm}$. long by $0.09 \mathrm{~mm}$. broad; C, D, E, hydrothecæ of different lengths, dimensions $0.53 \mathrm{~mm}$. long by $0.09 \mathrm{~mm}$. broad, $0.66 \mathrm{~mm}$. by $0.09 \mathrm{~mm}$., and $0.95 \mathrm{~mm}$. by $0.11 \mathrm{~mm}$. respectively; $\mathrm{F}$, showing formation of a growth ring.
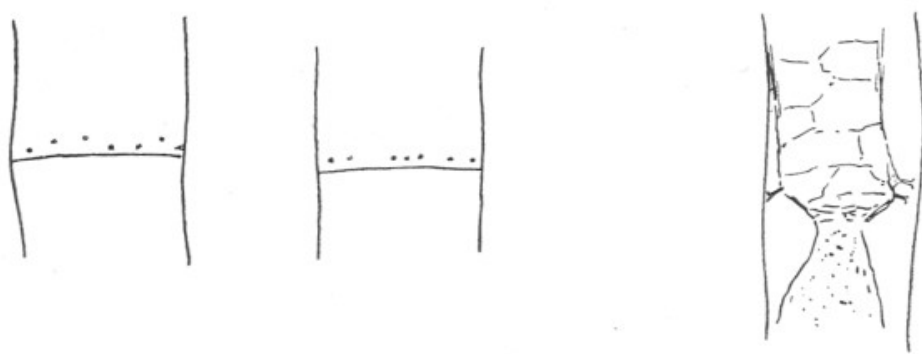

A

B

Fig. 5.-Base of Cuspidella hydrotheca reared from Laodicea at Plymouth, September, 1935. A, showing diaphragm and spines; B, showing apparent attachment of basal hydranth tissue to spines.

hydrotheca (Fig. 4, B). Most of the polyps developed eight tentacles, but in some there were only six and in one there were ten. Half the number of tentacles are short and half are long; and these alternate one 
with the other. In life the long tentacles, which arise slightly nearer the apex than the short ones, are held forwards, while the shorter tentacles stand out at right angles or pointing slightly backwards. The tentacles bear a number of nematocysts in ring-like clusters.

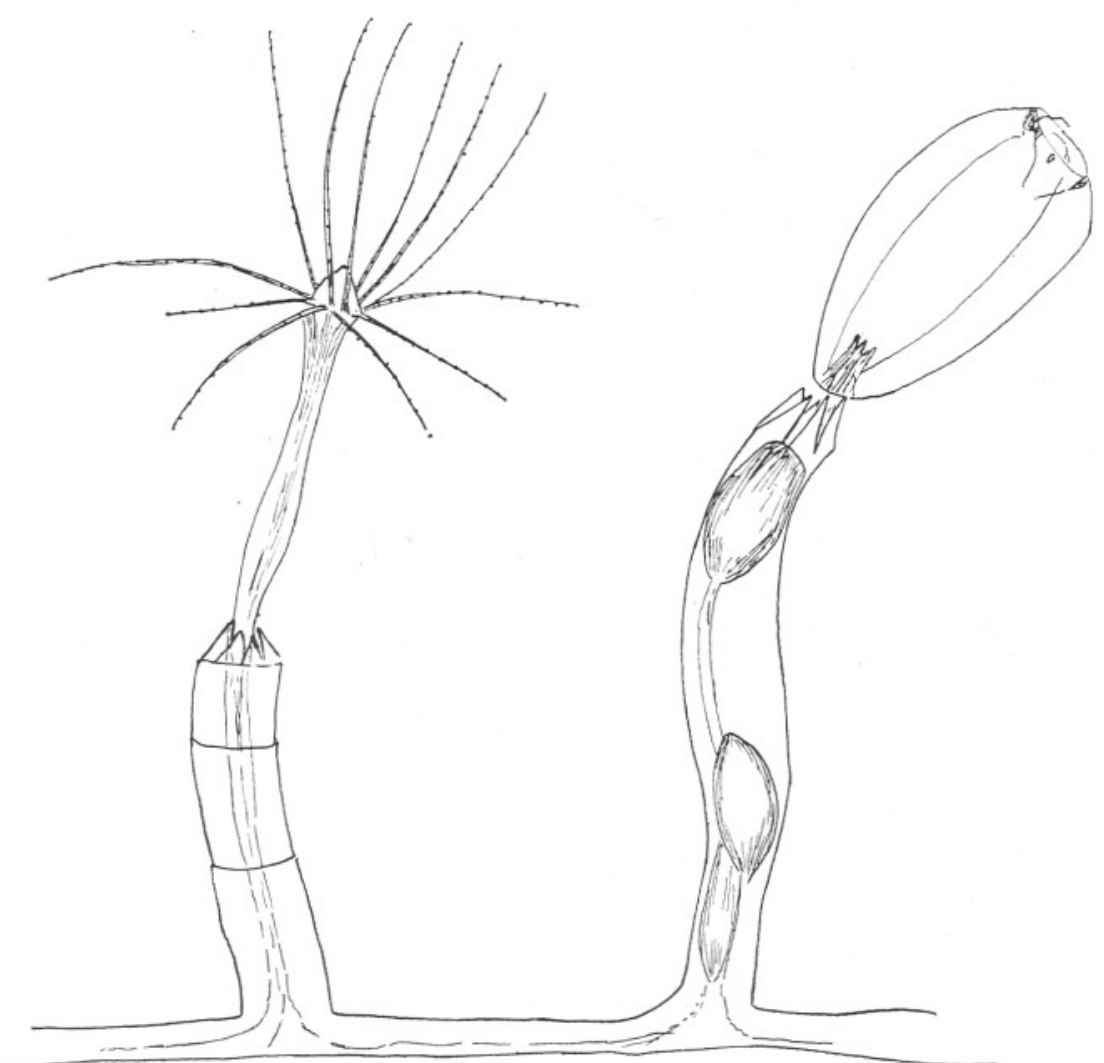

FIG. 6.-Hydrotheca and gonotheca of Cuspidella. From a tracing of the original pencil drawing by Miss M. J. Delap. Miss Delap's notes ran as follows : "Hydroid found 13.iii.06. A colony of Cuspidella costata on shell has been kept under observation and on 14.vi.06 a number of small medusæ were seen in same tank. The shell was isolated in a beaker and watched and the medusæ seen liberated. The gonotheca is very similar in shape to the hydrotheca and has a similar operculum, but no rings on stem. The medusa is very small, $8 / 10 \mathrm{~mm}$. across and about $1 \mathrm{~mm}$. high, two opposite tentacles and two opposite bulbs. No sense organs. Two small tentacles or filaments between the bulbs and tentacles. Can it be Laodice?

I reared a hydroid from what I thought were eggs of Laodice, Sept. '01, and a Cuspidella-like hydroid was the result. The hydroid only lived a short time."

There can now be no doubt that the hydroid of Laodicea undulata is a species of Cuspidella, and the early work of Metschnikoff and Delap is thus confirmed. The original drawings made by Miss Delap have never been published. Since these include drawings both of the gonotheca and 
of the newly liberated medusa it is fitting that they should be reproduced here (Figs. 6 and 7). I am greatly indebted to Miss M. J. Delap for her permission to publish these drawings and to Mr. E. T. Browne, in whose care they have lain for so many years, for the suggestion. The newly liberated medusa has already been described by Browne (1907, p. 465).

The above observations raise the question of the validity of certain Cuspidella species. Browne (1907, p. 464) has already suggested that C. humilis Hincks and C. costata Hincks are the same species. It appears possible that C. grandis Hincks should also be included; while the form of growth of the hydrothecæ in a number of the specimens reared at
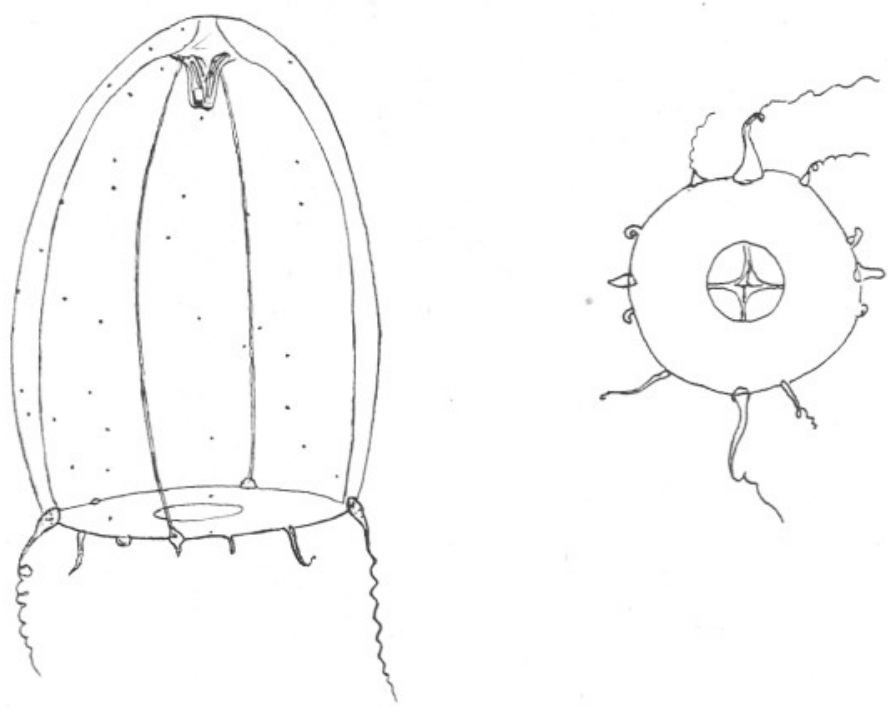

Fig. 7.-Medusæ liberated from Cuspidella. From a tracing of the origina. pencil drawing by Miss M. J. Delap. For Miss Delap's descriptive notes see Figure 6.

Plymouth resembles very closely that of Kramp's C. procumbens (1911, p. 384 and Pl. XXIV, Figs. 2-6). Hartlaub (1897, Taf. XX, Figs. 17 and 18) figures two individuals of $C$. grandis; he mentions that the hydrotheca cannot accurately be described as sessile, but that it passes over continuously into the perisarc of the hydranth stalk which at its base shows weak indications of ringing. Spassky (1929, Taf. II, Figs. 10-12) figures $C$.grandis (?) with clearly marked rings.

Cuspidella-like hydroids have however been reared from Mitrocoma annce by Metschnikoff (1886, p. 82, and Taf. IV, Figs. 15 and 16), and by Delap from Cosmetira pilosella and Dipleurosoma typicum. Until hydroids have been reared from these medusæ again and carefully compared it will not be possible to come to any final conclusions on the validity of the different Cuspidella species. 


\section{REFERENCES.}

Browne, Edward T. 1907. A Revision of the Medusæ belonging to the Family Laodiceidas. Ann. Mag. Nat. Hist., Ser. 7, Vol. XX, pp. 457480 .

Hartlaub, Clemens. 1897. Die Hydromedusen Helgolands. Wiss. Meeresunter. Abt. Helgoland, N.F., Bd. II, pp. 449-536 ; Taf. XIVXXIII.

Huncks, Thomas. 1868. A History of the British Hydroid Zoophytes. Vols. I and II.

Kramp, P. L. 1911. Report on the Hydroids collected by the Danmark Expedition at North-east Greenland. Medd. om Grønland, Bd. XLV, 1912, VII, pp. 341-396; Pl. XX-XXV.

Kramp, P. L. 1919. Medusæ. Part I. Leptomedusæ. The Danish Ingolf-Expedition, Vol. V, 8, pp. 1-111 ; Pl. I-V.

Kramp, P. L. 1932. The Godthaab Expedition 1928. Hydroids. Medd. om Grønland, Bd. 79, Nr. 1, pp. 1-86.

Metschnikoff, Elias. 1886. Embryologische Studien an Medusen. Ein Beitrag zur Genealogie der Primitiv-Organe. Wien. pp. 1-159. Atlas, Taf. I-XII.

Rrtchie, James. 1910. The Marine Fauna of the Mergui Archipelago, Lower Burma, collected by Jas. J. Simpson, M.A., B.Sc., and R. N. Rudmose-Brown, D.Sc., University of Aberdeen, February to May, 1907, Proc. Zool. Soc., London, pp. 799-825.

Spassky, N. 1929. Beiträge zur Kenntniss der Hydroidenfauna des Kola-Fjordes und des Süd-Westlichen Teiles der Barents-See. Trav. Stat. Biol. Murman, Vol. III, pp. 1-48; Taf. I-IV. (In Russian with a German Résumé.) 